\title{
The effect of ethyl acetat fraction of Caesalpinia sappan L. wood on PC3 cancer cell line : cell viability and migration study
}

DOI: https://doi.org/10.22435/hsji.v11i2.2349

\author{
Suyatmi Suyatmi ${ }^{1,2}$, Endang Listyaningsih Suparyanti ${ }^{1,2}$, Riza Novierta Pesik ${ }^{3}$ \\ ${ }^{1}$ Department of Histology, Faculty of Medicine, Universitas Sebelas Maret, Indonesia \\ ${ }^{2}$ Doctoral Program of Medicine, Universitas Sebelas Maret, Indonesia \\ ${ }^{3}$ Departmen of Pathology Anatomy, Faculty of Medicine, Universitas Sebelas Maret, Indonesia
}

Corresponding author: Suyatmi Suyatmi

Email: suyatmi72@staff.uns.ac.id

Received: October 2, 2019; Revised: November 18, 2019; Accepted: October 16, 2020

\begin{abstract}
Abstrak
Latar belakang: Tingginya insidensi kanker di Indonesia, termasuk kanker prostat menimbulkan beban ekonomi kesehatan yang tinggi bagi Indonesia. Pengembangan terapi kanker berbasis sumber daya alam lokal dapat membantu meringankan beban negara. Penelitian ini bertujuan untuk mengetahui potensi aktivitas anti-kanker fraksi ethyl acetat Caesalpinia sappan L. terhadap sel line kanker PC3 yang merupakan model in vitro kanker prostat.
\end{abstract}

Metode: Fraksi ethyl acetat kayu secang (Caesalpinia sappan L.) diperoleh melalui proses liquid chromatography. Efek fraksi 9 dari Ffraksi ethyl acetat kayu secang terhadap aktivitas anti-proliferasi dan migrasi sel diuji menggunakan desain uji in vitro. Hambatan proliferasi sel diukur dengan metode MTT assay, sedangkan aktivitas migrasi sel diukur dengan metode migration assay

Hasil: Fraksi 9 dari fraksi ethyl acetat kayu secang memperlihatkan hambatan proliferasi sel line kanker PC3 dengan IC50:14.99 $\mathrm{g} / \mathrm{ml}$. Hasil migration assay menunjukkan pada dosis $10 \mu \mathrm{g} / \mathrm{ml}$ fraksi

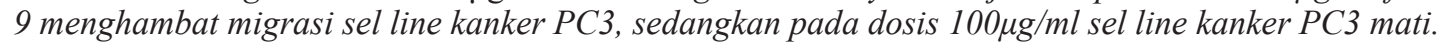

Kesimpulan: Fraksi 9 dari fraksi ethyl acetat kayu secang menunjukkan aktifitas anti-proliferasi dan antimigrasi yang kuat terhadap pertumbuhan sel line kanker PC3 secara in vitro. (Health Science Journal of Indonesia 2020;11(2):100-5)

Kata kunci: ethyl acetat fraction, Caesalpinia sappan, prostate cancer, PC3, migrasi sel

\begin{abstract}
Background: The high incidence of cancer, including prostate cancer, in Indonesia create a high burden on health economic cost. Development of cancer therapy based on local natural resources may help the country to alleviate the burden. This research aimed to find out the potency of selected compound of ethyl acetate fractions of Caesalpinia sappan as anti-cancer by using PC3 cancer cell line as an in vitro model of prostate cancer.
\end{abstract}

Methods: Ethyl acetate fraction of Caesalpinia sappan L. heartwood was prepared using a liquid chromatography method. The effect of ethyl acetate fraction 9 on anti-proliferative and cell migration activities was assessed using MTT assay and migration assay.

Results: Fraction-9 of ethyl acetate fraction of Caesalpinia sappan L. wood showed inhibition of PC3 cancer cell line proliferation. The IC50 of the fraction was $14.99 \mu \mathrm{g} / \mathrm{ml}$. The migration assay showed inhibition of cell migration on dose $10 \mu \mathrm{g} / \mathrm{ml}$ compared to the 0 doses, while most of the cells cultured was dead when treated with $100 \mu \mathrm{g} / \mathrm{ml}$ fraction 9.

Conclusion: Ethyl acetate fraction 9 of Caesalpinia sappan L. heartwood possibly has anti-cancer properties based on its anti-proliferative and anti-migration activities against PC3 cancer cell line. (Health Science Journal of Indonesia 2020;11(2):100-5)

Keyword: ethyl acetate fraction, Caesalpinia sappan, prostate cancer, PC3, cell migration 
The increasing cancer incidence worldwide put the disease on the high rank of global health challenge. The high mortality rate of the cancer patient and the expensive cost of cancer therapy justify cancer as a catastrophic disease. ${ }^{1}$ Global cancer observatory (Globocan) reported 11.361 new prostate cancer cases in 2018 in Indonesia. The incidence rate and mortality rate of prostate cancer are in the third rank among other cancer in the male in Indonesia. ${ }^{2}$

The application of the screening method on patients with urologic symptoms increases the detection rate of prostate cancer. ${ }^{3}$ Current therapeutic approaches for prostate cancer in Indonesia include surgery, External Beam Radiation Therapy, and Adjuvant Androgen Deprivation Therapy. ${ }^{4}$ Although advanced cancer therapy has been available nowadays, the cost of cancer therapy hampers many cancer patients from low-income society to seek immediate and appropriate cancer treatment. This condition urges the need to investigate the potential use of local plant medicine as cancer therapy.

In this study, we report the anti-cancer activity of one of Indonesian plant medicine, known with local name as secang. The Latin name of Secang is Caesalpinia sappan L. The heartwood of Caesalpinia sappan has been widely used as Javanese traditional medicine. ${ }^{5}$ In the field of cancer research, attention has been largely spent to study the potential anti-cancer activity of compounds isolated from Caesalpinia sappan L. Caesalpinia sappan heartwood contains many active compounds with anti-cancer activities including protosappanin $\mathrm{B}^{6}$ Brazilein, ${ }^{7}$ Brazilin $^{8}$. Brazilin is the major compound of Caesalpinia sappan L. heartwood which gives the red color when dissolved in water. ${ }^{9}$ This study investigated the anti-cancer activity of the ethyl acetate fraction of Caesalpinia sappan on PC3 cancer cell line.

\section{METHODS}

The experiment was conducted under the Ethical Approval issued by The Health Research Ethics Committee of Faculty of Medicine Universitas Sebelas Maret No. 59/UN27.6/KEPK/2018.

\section{Preparation of ethyl acetate fraction of Caesalpinia sappan $L$.}

Caesalpinia sappan heartwood was obtained from an herbal store in Surakarta, Central Java. An amount of $180 \mathrm{~g}$ of Caesalpinia sappan heartwood powder was macerated in $1 \mathrm{~L}$ of methanol ${ }^{\circledR}$ (Sigma) for 24 hours. The methanolic soluble compound was filtered using Whatman paper. The process was repeated three times. The filtrate of the methanolic soluble compound was then subjected to rotary evaporation to get concentrated crude methanolic extract. The methanolic extract was partitioned using n-hexane ${ }^{\circledR}$ (Sigma): ethyl acetate ${ }^{\circledR}$ (Sigma) $(\mathrm{v}: \mathrm{v})$ to separate the non-polar compound from the polar compound. The $n$-hexane soluble fraction was taken out and filtered. The ethyl acetate soluble fraction was then concentrated and applied to a silica gel column using 1:9 of Chloroform: Ethyl Acetate eluent. The final process yielded 24 separated fractions. All the fractions were subjected to a rotary evaporator to remove ethyl acetate residue. One hundred and twenty (120) mg of fraction-9 with yellowish red color was used in this experiment. The selection of Fraction-9 was based on the physical reference of Brazilin. ${ }^{10,11}$ Further identification of Fraction-9 compound was conducted by using comparative HPLC with Brazilin ${ }^{\circledR}$ (Sigma) as standard. The stock solution used in anti-proliferative and migration assay was made by dissolving Fraction-9 with cell culture grade of Dimethyl Sulfoxide (DMSO ${ }^{\circledR}$ ) from Sigma. The DMSO concentration on the tested fraction was adjusted not to exceed $0.1 \%$ for all of the experiments.

\section{Anti-proliferative assay}

Anti-proliferative activity of ethyl acetate fraction of Caesalpinia sappan wood was measured using MTT assay. PC3 cancer cell line was used as an in vitro model of prostate cancer. ${ }^{12}$ RPMI 1640 culture medium supplemented with $10 \%$ FBS and $1 \%$ Penicillin + Streptomycin was used. A number of $1 \times 10^{4}$ cells were seeded in 96-well microplates and incubated in $37^{\circ} \mathrm{C}$ and $5 \% \mathrm{CO}_{2}$. After 24 hours the medium was replaced with $100 \mu$ medium containing-serial concentration $(100,50,25$, $12.5,6.25,3.125,1.55$, and $0 \mu \mathrm{g} / \mathrm{ml})$ of the tested fraction. The cells were incubated for the next 24 hours. After 24 hours the culture medium was replaced with $100 \mu \mathrm{l}$ MTT stock solution $(5 \mathrm{mg} / \mathrm{ml}$, Sigma, St. Louis, MO) and incubated for 4 hours on $37^{\circ} \mathrm{C}$ and $5 \% \mathrm{CO}_{2}$. Sodium Dodecyl Sulphate (SDS) $10 \%$ in $0.1 \mathrm{~N} \mathrm{HCl}$ was added as stop solution after 4 hours incubation, and the plate was wrapped with aluminum foil and kept at room temperature overnight. The absorbance was measured at 570 $n m$ wavelength using ELISA reader $\left(\right.$ Biorad $\left.^{\circledR}\right)$ All 
the measurements were performed in triplicate. The cell viability was measured by comparing the optical density of the treated (dose $100-1.55 \mu \mathrm{g} / \mathrm{ml}$ ) and the non-treated (dose $0 \mu \mathrm{g} / \mathrm{ml})$ cells as a reference. The data were presented as the percentage of cell viability.

\section{Migration assay}

The experiment was conducted using a 6 well plate. Following the standard procedure on migration assay $^{13}$, an amount of $7 \times 10^{5} \mathrm{PC} 3$ cancer cell line/ well was seeded in 6 well plate. RPMI 1640 culture medium supplemented with $10 \%$ FBS and 1\% Penicillin and Streptomycin were used. The cells culture reached the monolayer, after 24 hours of incubation at $37^{\circ} \mathrm{C}$ and $5 \% \mathrm{CO}_{2}$. The wound was made by scratching the monolayer cells using a $200 \mu 1$ pipet tip. After scratching, the monolayer was carefully washed using PBS to remove the cell's debris. The culture medium was replaced with a medium containing 0,10 , and $100 \mu \mathrm{g} / \mathrm{ml}$ of fraction-9. The picture of the wound was taken at 0 and 18 hours after the scratching by using an inverted microscope. The cell migration was measured by the narrowing of cell free area (the width of the wound area) during the experiment time. The width of the wound area was measured using ImageJ software (NIH, Bethesda, MD). The cell migration was expressed as the reduction of the width of the cellfree area or the proximity of the wound edge.

\section{RESULTS}

\section{Identification of selected compound from ethyl acetate fraction (fraction-9)}

The HPLC analysis performed using HPLC system (Shimadzu Corp., Tokyo, Japan). The eluent system consisted of an isocratic mode of $100 \%(\mathrm{v} / \mathrm{v})$ Methanol, running at a flow rate of $0.5 \mathrm{ml} / \mathrm{min}$ at a column temperature of $25^{\circ} \mathrm{C}$. The spectrometric result of comparative HPLC showed in the Figure1.

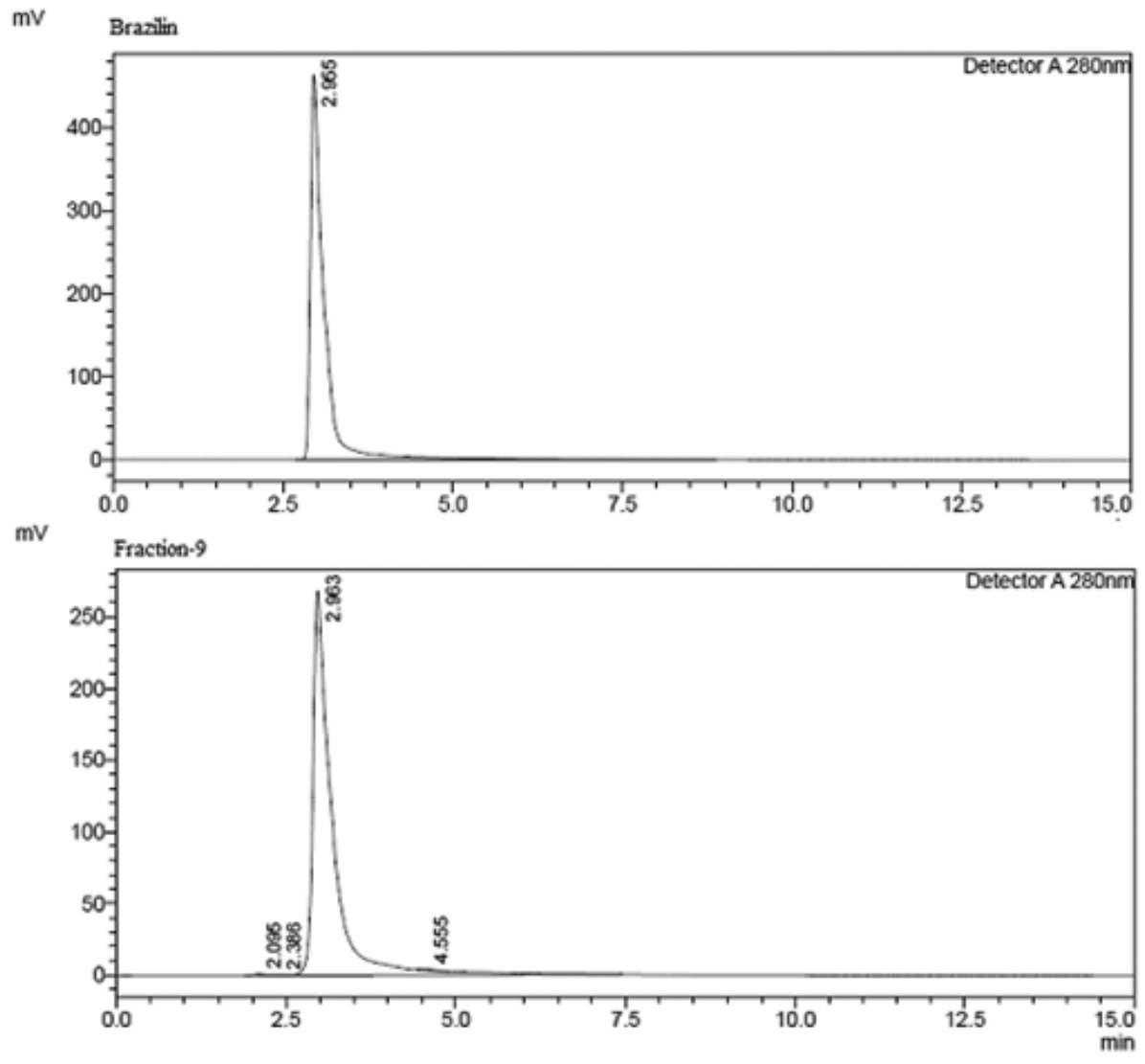

Figure 1. HPLC Chromatograph of Brazilin ${ }^{\circledR}$ and Fraction-9.

The peak of fraction- 9 at the same retention time indicates that brazilin is the major compound of fraction-9. 


\section{Anti-proliferative assay}

The result of anti-proliferative assay of fraction-9 on PC3 cancer cell line was shown in Figure 2. The fraction-9 was markedly showed a dose-dependent anti-proliferative effect on the cell. The increase of F9 concentration resulting in a decrease in the percentage of the viable cell. The IC50 of the compound was calculated using the following equation ${ }^{14}$.

$$
\text { IC50 }=\frac{(X 2-X 1) x(50-Y 1)}{(Y 2-Y 1)}+X 1
$$

$\mathrm{X} 1 / \mathrm{X} 2=$ the higher/the lower concentration bordering the concentration that reduces the cell growth of $50 \%$

$\mathrm{Y} 1 / \mathrm{Y} 2=$ percentage of viable cells at concentration $\mathrm{X} 1 / \mathrm{X} 2$

The IC50 of fraction-9 acquired by the calculation was $14.99 \mu \mathrm{g} / \mathrm{mL}$.

\section{Migration assay}

The migration assay showed that fraction-9 of ethyl acetate fraction extracted from Caesalpinnia sappan capable of inhibiting the migration of $\mathrm{PC} 3$ cancer cell line from the scratch line to the middle part of the wound. Figure 3 and Figure 4 showed that the addition of fraction-9 on PC3 cancer cell line monolayer after scratching inhibits cell migration activity. The migration activity was calculated as a percentage of the closure of the wound edge at 18 hours in respect to those at 0 hours. The percentage of the closure of the wound edge was calculated using the following formula ${ }^{15}$ :

$$
\text { wound closure } \%=\frac{A t 0 h-A t \Delta h}{A t 0 h} \times 100 \%
$$

$\mathrm{A}_{\mathrm{t} 0 \mathrm{~h}}=$ the area of the wound measured immediately after scratching $\left(\mathrm{t}_{\mathrm{oh}}\right)$

$\mathrm{A}_{\mathrm{t} \Delta \mathrm{h}}=$ the area of the wound measured $\Delta$ hours after the scratch is performed

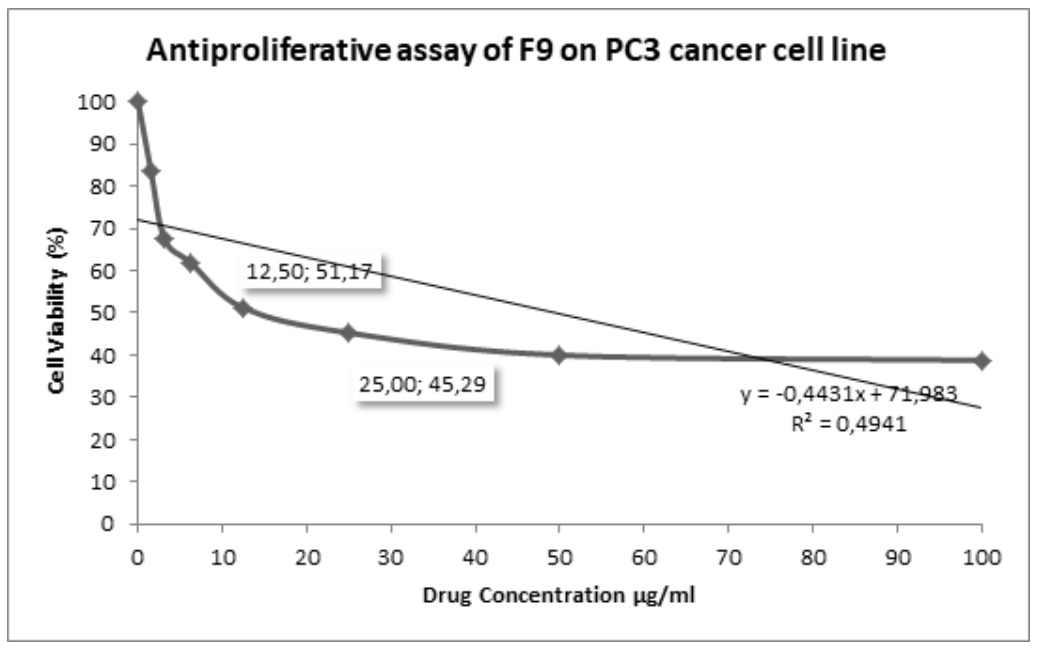

Figure 2. MTT Assay

The graphic showed a dose dependent effect of Fraction-9 on the percentage of PC3 cancer cell line viability. The $\mathrm{IC}_{50}$ of the fraction-9 was $14.99 \mu \mathrm{g} / \mathrm{ml}$.

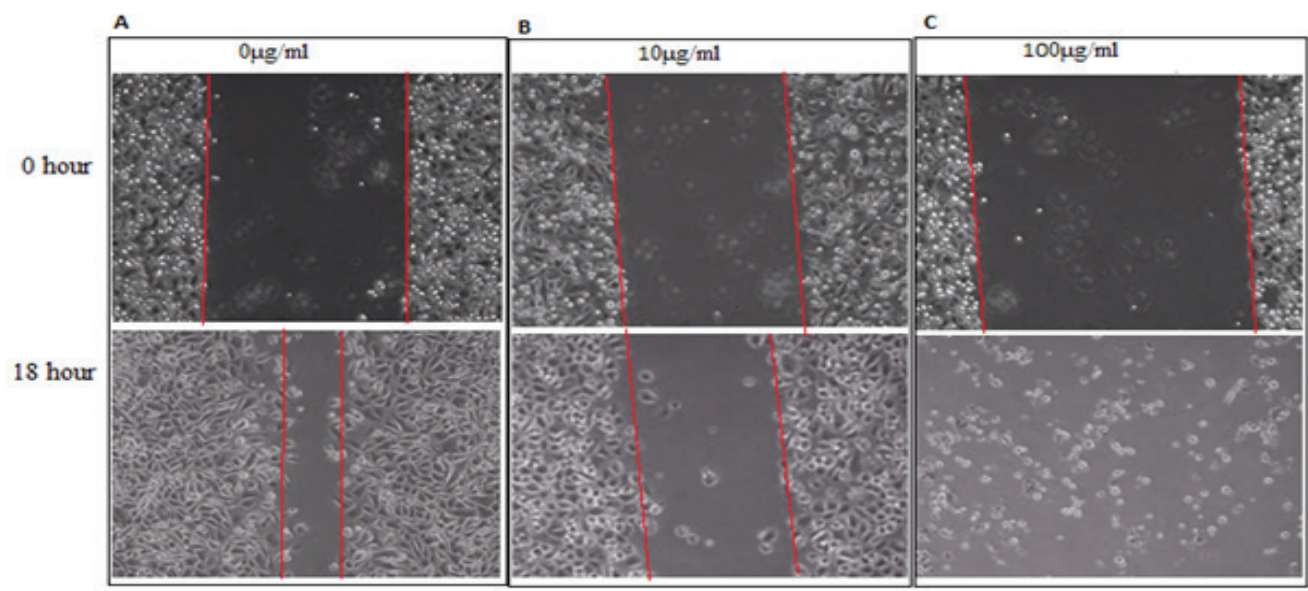

Figure 3 The effect of Fraction 9 on PC3 cancer cell line migration. A. The cell free area of PC3 cancer cell line monolayer without addition of Fraction $9(0 \mu \mathrm{g} / \mathrm{mL})$ at 0 and 18 hours after scratcing. B. The cell free area of PC3 cancer cell line monolayer treated with $10 \mu \mathrm{g} / \mathrm{mL}$ of Fraction 9 at 0 and 18 hours after scratcing. C. The cell free area of $P C 3$ cancer cell line monolayer treated with $100 \mu \mathrm{g} / \mathrm{mL}$ of Fraction 9 at 0 hour after scratcing (upper) and at 18 hours after scratching most of the cells died (lower). 


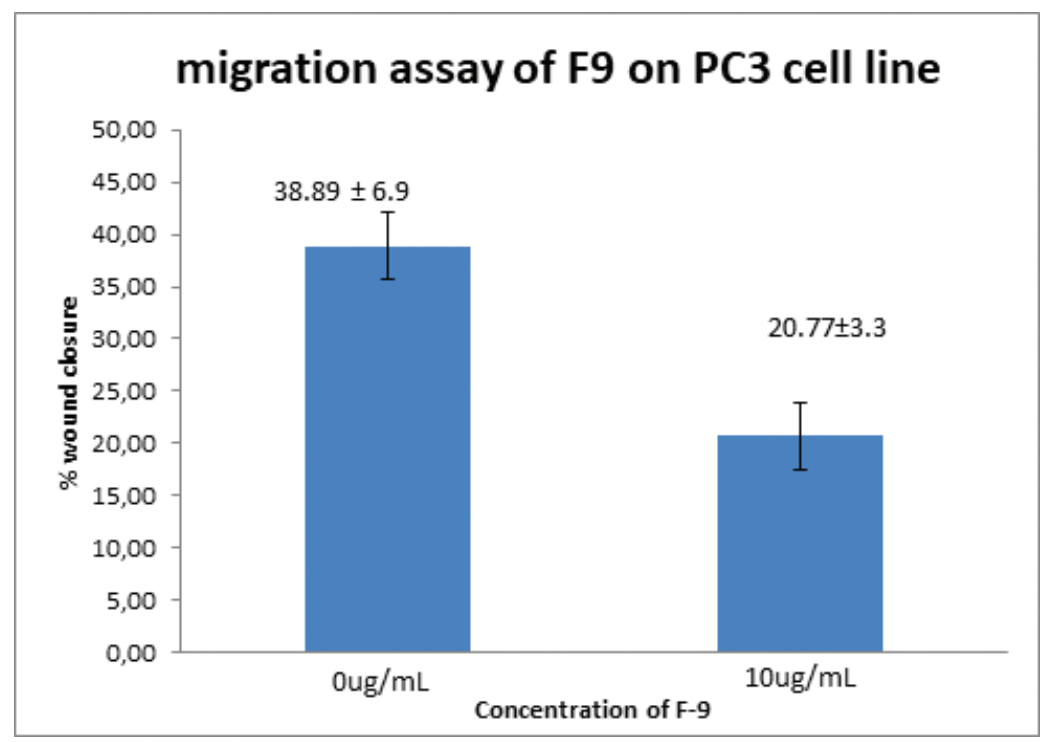

Figure 4. The effect of Fraction 9 of Ethyl acetate fraction of Caesalpinia sappan L. heartwood on PC3 cancer cell line migration. Cell migration was presented as a percentage of wound closure. Treatment of PC3 cancer cell line monolayer after scratching decreases the percentage of wound closure as compared to the control.

Figure 3 showed the highest percentage of cell migration on the untreated cells $(0 \mu \mathrm{g} / \mathrm{ml})$. The cellfree area was wider in cells treated with $10 \mu \mathrm{g} / \mathrm{ml}$ of fraction-9 than those in the untreated cells. The migration activity presented as the percentage of wound closure were $38.89 \% \pm 6.920 .7 \%$ and $20.77 \%$ $\pm 3.3 \%$ for untreated cell and $10 \mu \mathrm{g} / \mathrm{ml}$ Fraction-9 treated cell respectively.

\section{DISCUSSIONS}

Brazilin is considered the major compound of Caesalpinia sappan. heartwood. ${ }^{10}$ The data resulted from the comparative HPLC of fraction-9 with Brazilin ${ }^{\circledR}$ as standard compound indicated that Fraction-9 consisted mainly of brazilin. As can be shown in the chromatography of HPLC, many other compounds in small proportion were still mixed in fraction-9. Although fraction-9 was not a purified compound, it showed strong cytotoxic activity toward the growth of the PC3 cancer cell line. The IC50 of fraction-9 in this study was $14.99 \mu \mathrm{g} / \mathrm{mL}$.

The anti-proliferative activity of fraction-9 selected from the Ethyl acetate fraction of Caesalpinia sappan heartwood was markedly different from the anti-proliferative activity of methanolic extract of Caesalpinia sappan reported in a previous study, where the IC50 of methanolic extract of Caesalpinia sappan was $48 \mu \mathrm{g} / \mathrm{ml}$ on MCF-7 cell line. Fraction-9 also exhibits a higher cytotoxic activity compared to the cytotoxic activity of ethyl acetate fraction reported on HeLa, MCF-7/Moc, MCF-7/Her2, and T47D cancer cells, where the range of IC50 were 40 $-65 \mu \mathrm{g} / \mathrm{mL} .^{17-19}$

Investigation on anti-cancer activity of purified brazilin showed a potential anti-cancer activity of brazilin. Kim et al. reported high cytotoxic activity of brazilin on MM cells (U266 and MM1s), leukemia

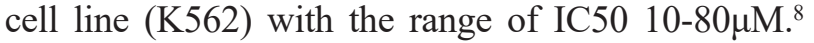
Ren et al. also reported the inhibition ratio of brazilin purified from sappan wood on the bladder cancer cell line (T24). The study reported the 50\% inhibition ratio of brazilin on the T24 cell line was $25.81 \mu \mathrm{g} / \mathrm{mL}{ }^{20}$ Compare to the anti-proliferative activity of purified Brazilin, the result of this study showed a promising potency to inhibit cancer cell proliferation. However, the cytotoxic dosage of fraction 9 on PC3 cancer cell line was higher than the dose of Doxorubicine and Docetaxel reported by Tsakalozou et al. where the IC50 of Doxorubicine and Docetaxel on PC3 cancer cell line were $0.598 \mathrm{nM}$ and $0.469 \mathrm{nM}$ respectively. ${ }^{21}$

The anti-migratory activity of fraction 9 was evaluated on PC3 cancer cell line in this study. The cell migration activity was examined using woundhealing assay. This method measure cell migration activity as the rate of wound closure. The result of this study showed that fraction-9 inhibits wound closure on dosage $10 \mu \mathrm{g} / \mathrm{mL}$. PC3 cancer cell line treatment with $10 \mu \mathrm{g} / \mathrm{L}$ of fraction-9 resulting in $22.77 \%$ of wound closure, while the wound closure of untreated PC3 cancer cell line was $38.89 \%$. This 
anti-migratory effect was comparable with other reported studies on purified Brazilin, where treatment with $12.5 \mu \mathrm{M}$ of Brazilin inhibits up to $16 \%$ of $\mathrm{MCF} /$ Her2 cell migration. ${ }^{22}$

In conclusion, ethyl acetate fraction 9 of Caesalpinia sappan L wood possibly has anti-cancer properties based on its anti-proliferative and anti-migration activities against PC3 cancer cell line. Further study to optimize the compound, dosage, and anti-cancer mechanism of Caesalpinia sappan L. is required.

\section{Acknowledgment}

The author would like to thank Universitas Sebelas Maret for providing research funding. The author would also like to thank Prof. Yung Hsi Kao from National Central University, Taiwan for Laboratory support and the PC3 cancer cell line.

\section{REFERENCES}

1. Moeloek NF. Indonesia national health policy in the transition of disease burden and health insurance coverage. Med J Indones. 2017;26(1):3-6. Available from: http://dx.doi.org/10.13181/mji.v26i1.1975.

2. International Agency for Research on Cancer. Indonesia Source GLOBOCAN 2018. Available from: https://gco.iarc.fr/today/home.

3. Mochtar CA, Atmoko W, Umbas R, Hamid ARAH. Prostate cancer detection rate in Indonesian men. Asian J Surg. 2018; 41:163-9.

4. Umbas R, Safriadi F, Mochtar CA, Djatisoesanto W, Hamid ARAH. Urologic cancer in Indonesia. Jpn J Clin Oncol. 2015 June 25:708-12.

5. Mulyani H, Widyastuti S, Ekowati V. Tumbuhan herbal sebagai jamu pengobatan tradisional terhadap penyakit. J Penelit Hum. 2016 Oktober 21:73-91. Indonesian.

6. Yang X, Ren L, Zhang S, Zhao L, Wang J. Antitumor effects of purified Protosappanin B extracted from Lignum sappan. Integr Cancer Ther. 2016;15:87-95.

7. Tirtanirmala P, Novarina A, Utomo RY, Sugiyanto RN, Jenie RI, Meiyanto E. Cytotoxic and Apoptoticinducing effect of fraction containing Brazilein from Caesalpinia sappan $\mathrm{L}$. and Cisplatin on T47D cell lines. IJCC. 2015;6:89-96.

8. Kim B, Kim S, Jeong S, Sohn EJ, Jung JH, Lee MH, et al. Brazilin induces apoptosis and G2/M arrest via inactivation of histone deacetylase in multiple myeloma U266 cells. J Agric Food Chem. 2012;60:9882-9.

9. Fardhyanti DS, Riski RD. Jurnal Bahan Alam Terbarukan. J Bahan Alam Terbarukan. 2015;4(1):613. Indonesian.
10. Nirmal NP, Rajput MS, Prasad RGSV, Ahmad M. Brazilin from Caesalpinia sappan heartwood and its pharmacological activities: a review. Asian Pac J Trop Med. 2015;8(6):421-30.

11. Batubara I, Mitsunaga T, Ohashi H. Screening antiacne potency of Indonesian medicinal plants : antibacterial, lipase inhibition, and antioxidant activities. J Wood Sci. 2009;55:230-5.

12. Cunningham D, You Z. In vitro and in vivo model systems used in prostate cancer research. J Biol Methods. 2015;2(1):1-28.

13. Justus CR, Leffler N, Ruiz-echevarria M, Yang LV. In vitro cell migration and invasion assays. J Vis Exp. 2014; 88:1-8.

14. Mathieu V, Neve N De, Mercier M Le, Dewelle $\mathrm{J}$, Gaussin J-F, Dehoux M, et al. Combining Bevacizumab with Temozolomide increases the antitumor efficacy of Temozolomide in a human glioblastoma orthotopic xenograft model. Neoplasia. 2008; 10:1383-92.

15. Grada A, Otero-vinas M, Prieto-castrillo F, Obagi Z, Falanga V. Research techniques made simple: analysis of collective cell migration using the wound healing assay. J Invest Dermatol 2018;137:e11-6.

16. Suyatmi S, Azzumar F, Pesik RN, Indarto D. Potential anticancer activity of Caesalpinia sappan Linn., in silico and in vitro studies. In: The 1st International Conference on Health, Technology, and Life science (ICO-HELICS) Surakarta. KnE Life Sciences; 2019. p. 96-102.

17. Husnaa U, Putu N, Laksmiani L, Susidarti RA, Meiyanto E. Ethyl acetate fraction of Caesalpinia sappan L. enhances cisplatin's cytotoxicity on HeLa cells via $\mathrm{G} 1$ and $\mathrm{S}$ arrest through $\mathrm{p} 53$ expression. IJCC. 2017;8:51-60.

18. Jenie RI, Handayani S, Susidarti RA, Udin Z, Meiyanto E. Cytotoxic and Antimetastasis effect of Ethyl acetate fraction from Caesalpinia sappan L . on MCF-7 / HER2 cells. IJCC. 2017;8:42-50.

19. Utomo RY, Novarina A, Tirtanirmala P, Kastian RF, Jenie RI. Enhancement of Cytotoxicity and Apoptosis induction of Doxorubicin by Brazilein containing fraction of Secang (Caesalpinia sappan L .) on T47D cells. IJCC. 2018;9:32-40.

20. Ren L, Yang X, Wang G, Zhang H, Zhao L, Mi Z. Inhibition effect of Brazilin to human bladder. Int Sch Sci Res Innov. 2011;5:657-61.

21. Tsakalozou E, Eckman AM, Bae Y. Combination effects of Docetaxel and Doxorubicin in hormonerefractory prostate cancer cells. Biochemistry Research International. 2012 Juli: 1-10. Article ID 832059, https://doi.org/10.1155/2012/832059.

22. Jenie RI, Handayani S, Susidarti RA, Udin LZ, Meiyanto E. The Cytotoxic and Antimigratory activity of Brazilin-Doxorubicin on MCF7/Her2 cells. Adv Pharm Bull. 2018;8:507-16. 